\title{
Coastal Forest Seawater Exposure Increases Stem Methane Concentration
}

\author{
Matthew J. Norwood \\ Nicholas Ward \\ (.....) \\ Matthew L. Kirwan \\ Virginia Institute of Marine Science \\ Anya Hopple
}

See next page for additional authors

Follow this and additional works at: https://scholarworks.wm.edu/vimsarticles

Part of the Earth Sciences Commons

\section{Recommended Citation}

Norwood, Matthew J.; Ward, Nicholas; (......); Kirwan, Matthew L.; Hopple, Anya; and Megonigal, J. Patrick, Coastal Forest Seawater Exposure Increases Stem Methane Concentration (2021). JGR Biogeosciences, 126(2), e2020JG005915. doi: $10.1029 / 2020 J G 005915$

This Article is brought to you for free and open access by the Virginia Institute of Marine Science at W\&M ScholarWorks. It has been accepted for inclusion in VIMS Articles by an authorized administrator of W\&M ScholarWorks. For more information, please contact scholarworks@wm.edu. 
Authors

Matthew J. Norwood, Nicholas Ward, (......), Matthew L. Kirwan, Anya Hopple, and J. Patrick Megonigal 


\section{JGR Biogeosciences}

\author{
RESEARCH ARTICLE \\ 10.1029/2020JG005915 \\ Key Points: \\ - Seawater exposure significantly \\ increased internal stem $\mathrm{CH}_{4}$ \\ concentration \\ - There is a significant correlation \\ between stem wood density and \\ stem $\mathrm{CH}_{4}$ concentration \\ - Low stem and soil $\mathrm{O}_{2}$ were \\ significantly linked to seawater \\ exposure and decreased tree survival
}

Supporting Information:

- Supporting Information S1

Correspondence to:

M. J. Norwood,

matthew.norwood@pnnl.gov

Citation:

Norwood, M. J., Ward, N. D., McDowell, N. G., Myers-Pigg, A. N., BondLamberty, B., Indivero, J., et al. (2021). Coastal forest seawater exposure increases stem methane concentration. Journal of Geophysical Research: Biogeosciences, 126, e2020JG005915. https://doi.org/10.1029/2020JG005915

Received 16 JUN 2020

Accepted 21 DEC 2020

Author Contributions:

Conceptualization: Matthew J. Norwood, Nicholas D. Ward

Data curation: Matthew J. Norwood

Formal analysis: Matthew J. Norwood

Funding acquisition: Nicholas D.

Ward

Investigation: Matthew J. Norwood,

Nicholas D. Ward, Allison N. Myers-

Pigg, Ben Bond-Lamberty, Julia

Indivero, Stephanie Pennington,

Wenzhi Wang, Matt Kirwan

Methodology: Matthew J. Norwood,

Nicholas D. Ward

Project Administration: Nicholas

D. Ward

Supervision: Nicholas D. Ward, Nate

G. McDowell, J. Patrick Megonigal

Writing - original draft: Matthew

J. Norwood, Nicholas D. Ward, Nate

G. McDowell, Allison N. Myers-Pigg,

Ben Bond-Lamberty, Julia Indivero,

Stephanie Pennington, Wenzhi Wang,

(C) 2020. American Geophysical Union. All Rights Reserved.

\section{Coastal Forest Seawater Exposure Increases Stem Methane Concentration}

\author{
Matthew J. Norwood ${ }^{1}$ (D), Nicholas D. Ward ${ }^{1,2}$ (D), Nate G. McDowell ${ }^{3,4}$, \\ Allison N. Myers-Pigg ${ }^{1,5}$ (D), Ben Bond-Lamberty ${ }^{6}$ (D), Julia Indivero ${ }^{1,7}$ (D), \\ Stephanie Pennington $^{6}$ (D) Wenzhi Wang ${ }^{3,8}$ (D) Matt Kirwan' ${ }^{\text {(D) , Anya M. Hopple }}$, $^{4,10}$, and \\ J. Patrick Megonigal ${ }^{10}$ (D)
}

${ }^{1}$ Marine and Coastal Research Laboratory, Pacific Northwest National Laboratory, Sequim, WA, USA, ${ }^{2}$ School of Oceanography, University of Washington, Seattle, WA, USA, ${ }^{3}$ Atmospheric Sciences and Global Change Division, Pacific Northwest National Laboratory, Richland, WA, USA, ${ }^{4}$ School of Biological Sciences, Washington State University, Pullman, WA, USA, ${ }^{5}$ Biological Sciences Division, Pacific Northwest National Laboratory, Richland, WA, USA, ${ }^{6}$ Joint Global Change Research Institute, Pacific Northwest National Laboratory, College Park, MD, USA, ${ }^{7}$ Now at School of Aquatic and Fishery Sciences, University of Washington, Seattle, WA, USA, ${ }^{8}$ Now at Institute of Mountain Hazards and Environment, Chengdu, China, ${ }^{9}$ Virginia Institute of Marine Science, Gloucester Point, VA, USA,

${ }^{10}$ Smithsonian Environmental Research Center, Edgewater, MD, USA

Abstract Methane $\left(\mathrm{CH}_{4}\right)$ exchange between trees and the atmosphere has recently emerged as an important, but poorly quantified process regulating global climate. The sources (soil and/or tree) and mechanisms driving the increase of $\mathrm{CH}_{4}$ in trees and degassing to the atmosphere are inadequately understood, particularly for coastal forests facing increased exposure to seawater. We investigated the eco-physiological relationship between tree stem wood density, soil and stem oxygen saturation (an indicator of redox state), soil and stem $\mathrm{CH}_{4}$ concentrations, soil and stem carbon dioxide $\left(\mathrm{CO}_{2}\right)$ concentrations, and soil salinity in five forests along the United States coastline. We aim to evaluate the mechanisms underlying greenhouse gas increase in trees and the influence of seawater exposure on stem $\mathrm{CH}_{4}$ accumulation. Seawater exposure corresponded with decreased tree survival and increased tree stem methane. Tree stem wood density was significantly correlated with increased stem $\mathrm{CH}_{4}$ in seawater exposed gymnosperms, indicating that dying gymnosperm trees may accumulate higher levels of $\mathrm{CH}_{4}$ in association with seawater flooding. Further, we found that significant differences in seawater exposed and unexposed gymnosperm tree populations are associated with increased soil and stem $\mathrm{CH}_{4}$ and $\mathrm{CO}_{2}$, indicating that seawater exposure significantly impacts soil and stem greenhouse gas abundance. Our results provide new insight into the potential mechanisms driving tree $\mathrm{CH}_{4}$ accumulation within gymnosperm coastal forests.

Plain Language Summary Trees emit greenhouse gases such as methane and carbon dioxide to the atmosphere. The origin of these gases includes production in the tree or in the surrounding soils. Disturbances to these systems, such as seawater exposure that increases soil salinity, have an unknown impact on gas production and connectivity between soil and trees. We found that higher soil salinities corresponded to higher soil methane content and increased stem methane. The accumulation of soil and tree methane was lower in sites with no salinity exposure and higher in sites with high salinity. As coastal systems become more vulnerable to changes in seawater exposure, this may have consequences on methane emitted from trees to the atmosphere.

\section{Introduction}

Increasing atmospheric greenhouse gas (GHG) levels have resulted in polar warming that is projected to cause sea levels to rise substantially in the next century (de Coninck et al., 2018; Overpeck et al., 2006). The amount of methane $\left(\mathrm{CH}_{4}\right)$ in the atmosphere is increasing globally, representing an important positive feedback on climate warming that is regulated by numerous terrestrial and aquatic sources and sinks (Winterstein et al., 2019). Upland soils take up $30 \mathrm{Tg} \mathrm{CH}_{4} \mathrm{yr}^{-1}$, freshwater wetlands emit $\sim 150 \mathrm{Tg} \mathrm{CH}_{4} \mathrm{yr}^{-1}$, and wetlands exposed to seawater (e.g., salt marshes) are thought to play a net neutral role in global $\mathrm{CH}_{4}$ cycling (Poffenbarger et al., 2011; Saunois et al., 2016). Critical gaps in mechanistic understanding of how 
Matt Kirwan, Anya M. Hopple, J. Patrick Megonigal

Writing - review \& editing: Matthew J. Norwood, Nicholas D. Ward, Nate G. McDowell, Allison N. Myers-Pigg, Ben Bond-Lamberty, Julia Indivero, Stephanie Pennington, Wenzhi Wang, Matt Kirwan, Anya M. Hopple, J. Patrick Megonigal ecosystems exchange $\mathrm{CH}_{4}$ to and from the atmosphere inhibit our ability to quantify present day cycling and future responses to ecosystem disturbances such as warming, sea level rise, and changes in precipitation (Bridgham et al., 2013). Considering $\mathrm{CH}_{4}$ has a greenhouse gas warming potential 87-11 times greater than $\mathrm{CO}_{2}$ over 20 to 500-year timescales (Neubauer \& Megonigal, 2015), a mechanistic understanding of $\mathrm{CH}_{4}$ cycling is necessary for a predictive outlook on ecosystem response to change.

Natural ecosystems are faced with a variety of anthropogenic disturbances that may dramatically shift their biogeochemical function (Fichtner et al., 2014) and coupling or decoupling of different ecosystem components (e.g., rhizosphere-tree stem) (Mark et al., 2005; Noe et al., 2011; Willig et al., 1996). Increased coastal forest inundation events such as due to rising sea level and increasing storm frequency (Fagherazzi et al., 2019; Lin et al., 2020; K. Williams et al., 2003; C. A. Williams et al., 2016), ultimately may turn forests that were net carbon sinks to net carbon sources (Hadden \& Grelle, 2016). There have already been demonstrable changes in coastal ecosystems, with wetlands drowning and coastal forests dying (Kirwan \& Gedan, 2019; W. Wang et al., 2019), and upland terrestrial ecosystems also feeling pressure from increasing drought/flood cycles and rising temperatures (McDowell et al., 2018).

Environmental disturbances such as freshwater flooding (Pangala et al., 2017; Pitz et al., 2018) and salt intrusion (Ward et al., 2019) are expected to increase either the production of GHGs within tree stems or the export of GHGs from soils to the atmosphere. Environmental changes and/or disturbances to forest soil $\mathrm{CH}_{4}$ and $\mathrm{CO}_{2}$ source or sink functions can be influenced by changes to soil temperature, soil moisture content, and soil biogeochemistry (Bowden et al., 1993; King, 1997; Ni \& Groffman, 2018; Ojima et al., 1993; Raich \& Schlesinger, 1992). Environmental changes and/or disturbances to these ecosystems can influence $\mathrm{CH}_{4}$ and $\mathrm{CO}_{2}$ net greenhouse gas budgets (Bousquet et al., 2006; Dlugokencky et al., 2011). However, these responses are neither understood from a mechanistic perspective nor easily measured across spatial scales broad enough to reveal continental-to global-scale patterns. Therefore, gaining a mechanistic understanding on the effects of coastal forest flooding on soil/tree GHG cycling is important in predicting climate-induced carbon feedbacks.

Global $\mathrm{CH}_{4}$ budget estimates typically do not include an important pathway for gas exchange between soils and the atmosphere- $\mathrm{CH}_{4}$ emissions from woody vegetation (Barba et al., 2019; Bousquet et al., 2006; Covey \& Megonigal, 2019; Megonigal \& Guenther, 2008). Nonwoody vegetation has long been recognized as playing an important role in wetland $\mathrm{CH}_{4}$ exchange, yet little attention has been paid to the contributions of tree stems, despite the large surface area they represent in forested ecosystems (Crowther et al., 2015). The few examples in the literature have found that $\mathrm{CH}_{4}$ emissions from tree stems are locally (Covey \& Megonigal, 2019) and regionally relevant (Machacova et al., 2016; Pangala et al., 2017; Z. P. Wang et al., 2017), with the potential to offset the soil $\mathrm{CH}_{4}$ sink by up to 63\% (Covey \& Megonigal, 2019). Furthermore, $\mathrm{CH}_{4}$ emissions from trees represent a conduit for $\mathrm{CH}_{4}$ to escape from deeper soil layers to the atmosphere in ecosystems that are often considered $\mathrm{CH}_{4}$ sinks, such as upland forests (Carmichael et al., 2014; Covey et al., 2012; Le Mer \& Roger, 2001) and coastal floodplain forests (Ward et al., 2019).

The magnitude of tree $\mathrm{CH}_{4}$ exchange partially depends on the provenance of $\mathrm{CH}_{4}$ (i.e., soil vs. tree sources), transport pathways and mechanisms (i.e., diffusion vs. mass flow), and drivers of gas diffusion rates (e.g., stem morphology and stem water content) (Barba et al., 2019; Megonigal et al., 2020). The extent to which $\mathrm{CH}_{4}$ emissions from trees are coupled to soils will vary with each of these factors, which in turn are influenced by ecosystem disturbances. Flooding induced increases in soil saturation severely restricts exchange of oxygen $\left(\mathrm{O}_{2}\right)$ between the atmosphere, soil pore spaces, and tree pore spaces. Molecular $\mathrm{O}_{2}$ is consumed rapidly by aerobic plant and microbial respiration in soil and tree stems and can only be replaced by atmospheric gas flux through soil and tree pore spaces. As these spaces fill with water, diffusion pathways are effectively blocked as $\mathrm{O}_{2}$ diffusion rates decline 103-fold and $\mathrm{O}_{2}$ concentrations subsequently decline (Boyer et al., 1997; Collin \& Rasmuson, 1988). The development of hypoxic or anoxic conditions fundamentally alters the dominant pathways of microbial respiration, both in soils (Megonigal et al., 2003) and in tree stems (Covey \& Megonigal, 2019), and negatively impacts the physiology of plants that are not flood tolerant.

Here we use a new approach to discern coupling and decoupling of soil and tree stem biogeochemistry in order to identify the mechanisms by which tree stems accumulate and emit $\mathrm{CH}_{4}$ in response to seawater exposure. We measured tree stem wood density, concentrations of $\mathrm{O}_{2}, \mathrm{CO}_{2}$, and $\mathrm{CH}_{4}$ internally in gymnosperm 


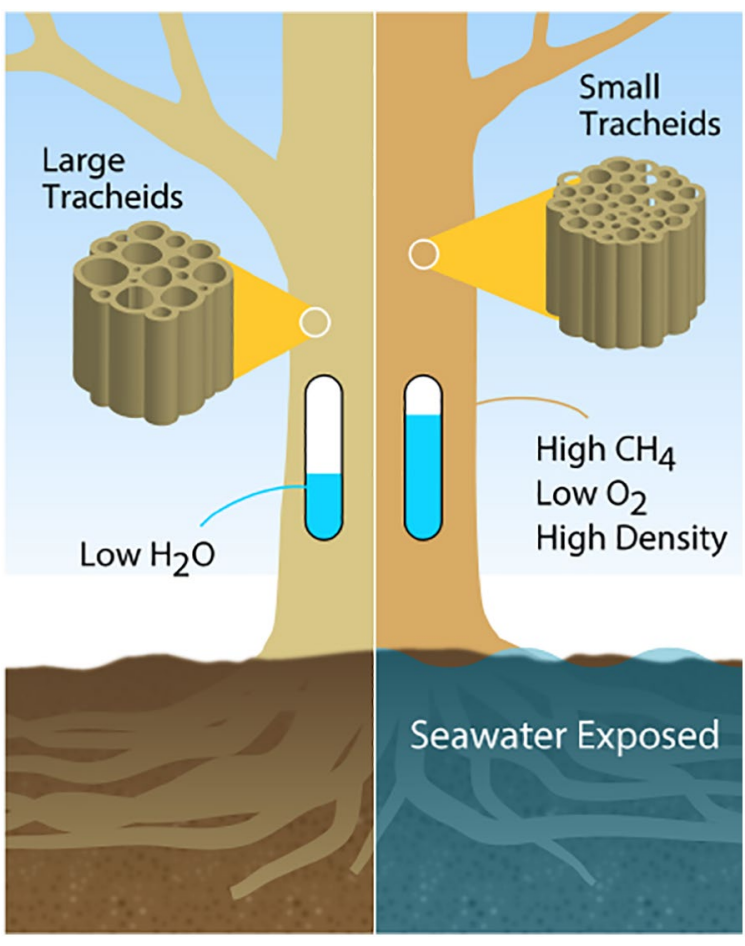

Figure 1. A conceptual diagram of the mechanisms driving soil-tree greenhouse $\mathrm{CH}_{4}$ exchange in seawater exposed coastal forests. Density can be affected by water content and/or tracheid size. Higher density results in higher internal stem $\mathrm{CH}_{4}$ and limited $\mathrm{O}_{2}$ diffusion. tree stems (a method that has been previously used with $\mathrm{CO}_{2}$ and $\mathrm{O}_{2}$ to study tree respiration [Cerasoli et al., 2009; Teskey \& Mcguire, 2007; Teskey et al., 2008]) and in soil pore spaces (liquid or gaseous phase depending on soil saturation) and interpret these data in the context of seawater exposed trees and unexposed trees. First, we hypothesize that seawater exposure will increase internal gymnosperm-stem $\mathrm{CH}_{4}$ and $\mathrm{CO}_{2}$ concentrations, compared to unexposed trees (Figure 1). Second, we hypothesize that seawater exposure will significantly increase stem wood density, with increased stem wood density significantly correlated with increased stem $\mathrm{CH}_{4}$ and $\mathrm{CO}_{2}$. Finally, we hypothesize that seawater exposure will have a significant effect on stem and soil gases $\left(\mathrm{CH}_{4}, \mathrm{CO}_{2}\right.$, and $\mathrm{O}_{2}$ ), with the relationship between GHGs in seawater exposed trees and unexposed trees uniquely clustered in a multivariant space.

\section{Materials and Methods}

\subsection{Study Sites}

Measurements of soil and tree stem $\mathrm{O}_{2}, \mathrm{CO}_{2}$, and $\mathrm{CH}_{4}$ concentrations were made at five sites representing two coastal eco-regions: the Mediterranean Pacific Northwest and the temperate Atlantic Eastern shore (Figure 2). In total, 107 trees were sampled, pairing stem and soil gas measurements for $\mathrm{CO}_{2}, \mathrm{CH}_{4}$, and $\mathrm{O}_{2}$, and average stem wood density (Table 1 and Norwood, 2020). The number of trees by tree species, seawater exposure, and tree survival are represented in Table 1. All stem gas and bulk soil gas samples were collected during daylight hours during the 2019 growing season (late June-early September). All stem density measurements were made at breast height on the north-facing side of the stem to reduce variability between sun exposed wood versus shaded wood (Mein-

zer et al., 2008; Rinn et al., 1996). We sampled five gymnosperm coastal forests, with two randomized nominal plots at each site, containing living and dying trees for both seawater exposed and unexposed locations (Table 1; Figure 2). Three soil measurements were collected within each plot for soil salinity and soil gases.

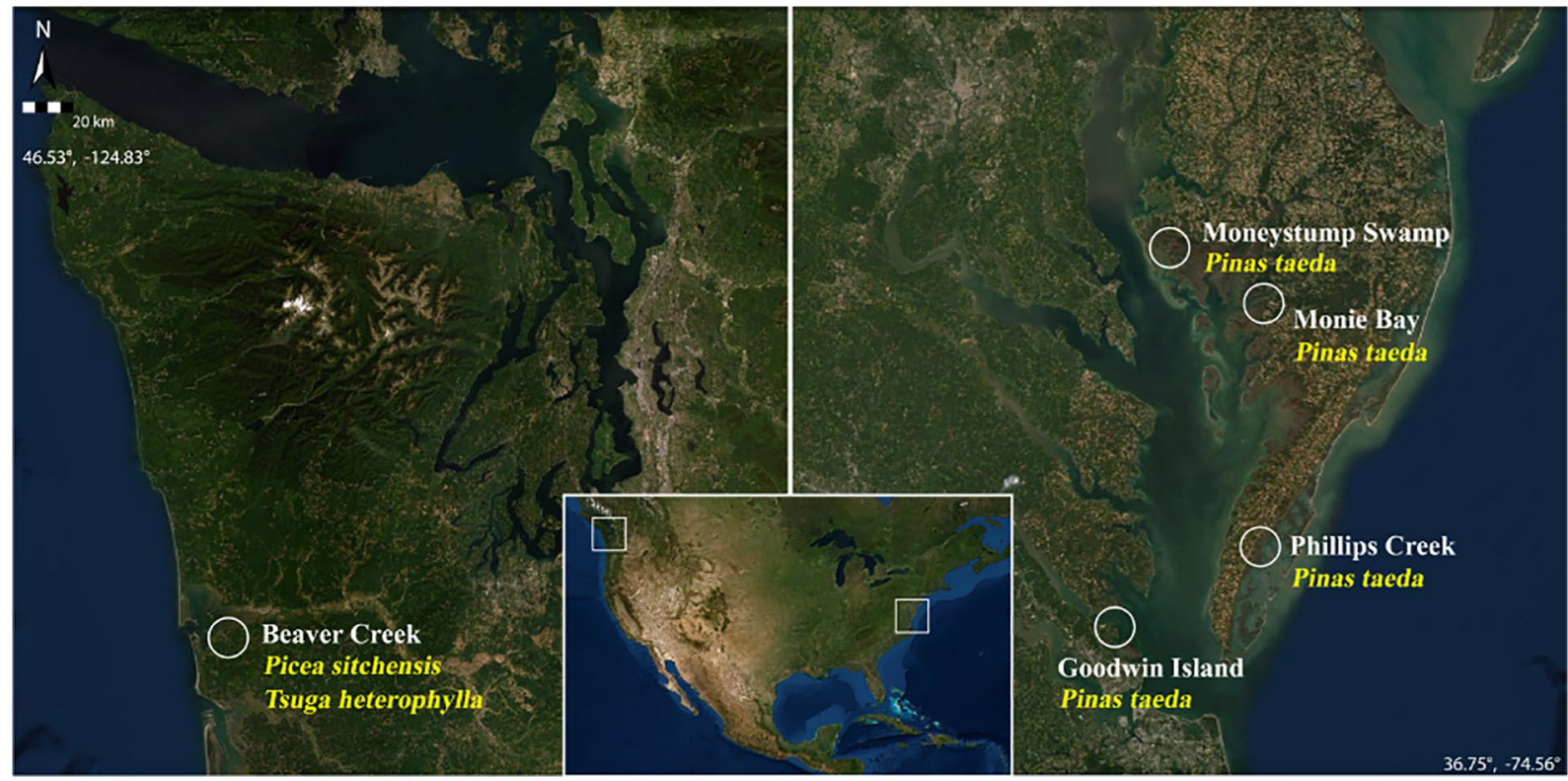

Figure 2. The five sites where trees and soils were sampled for percent $\mathrm{O}_{2}$ and internal stem $\mathrm{CO}_{2} \& \mathrm{CH}_{4}$ concentrations. Sites are denoted with tree species. Map was created using ArcGIS 10.5 software (ESRI, 2017). Coordinate system: GCS WGS 1984. 


\section{Table 1}

Distribution of Tree Samples for each Location by Tree Species ( $n=$ Total Number of Trees), Seawater Exposure (exp. = Exposed, unx. $=$ Unexposed), and Tree Survival (Living or Dying)

\begin{tabular}{llcccc}
\hline Location & \multicolumn{1}{c}{ Tree species } & Exp. & Unx. & Living & Dying \\
\hline Beaver Creek & P. sitchensis $(n=12)$ & 12 & 0 & 6 & 6 \\
& T. heterophylla $(n=6)$ & 3 & 3 & 6 & -- \\
Goodwin Island & P. taeda $(n=35)$ & 23 & 12 & 23 & 12 \\
Phillips Creek & P. taeda $(n=18)$ & 12 & 6 & 12 & 6 \\
Monie Bay & P. taeda $(n=18)$ & 12 & 6 & 12 & 6 \\
Moneystump & P. taeda $(n=18)$ & 12 & 6 & 13 & 5 \\
\hline
\end{tabular}

Note. Tree survival was estimated by percent canopy greenness (Wang et al., 2019).
Each plot consisted of an area larger than $100 \mathrm{~m}^{2}$, with soil measurements tied to each plot. Living and dying trees were randomly selected within each respective plot, with individual tree density and gas measurements recorded for each tree that was randomly selected within the plot.

Here we identify seawater exposure at each of the five sites (Figure 2). Beaver Creek, WA- a first order watershed with a previously freshwater swamp in its lowlands that became exposed to seawater inundation 5 years before sampling due to culvert removal and an undisturbed (nonflooded) upland forest (W. Wang et al., 2019). Beaver Creek is located in western Washington state (Pacific Northwest coast ecoregion). The climate in this region typically consists of dry summers and cool, wet winters, with a mean annual temperature of $10.4^{\circ} \mathrm{C}$ and an average annual precipitation of 1,640 $\mathrm{mm}$ from September to May (W. Wang et al., 2019; Ward et al., 2019). The Beaver Creek site includes two gymnosperm species, Picea sitchensis and Tsuga heterophylla, with 18 trees sampled total (12x P. sitchensis and 6x T. heterophylla).

Goodwin Island, Phillips Creek, Monie Bay, and Moneystump Swamp are coastal forest sites around Chesapeake Bay that are experiencing significant tree die off due to sea-level rise and nonflooded trees distal to shoreline (Kirwan \& Gedan, 2019; Schieder \& Kirwan, 2019; Schieder et al., 2018). Goodwin Island, Phillips Creek, Monie Bay, and Moneystump Swamp sites are located in a similar temperate climate, where naturally occurring stands of one gymnosperm species, Pinus taeda, are associated with coastal plain soils near tidal marshes (Brinson et al., 1995; Kirwan et al., 2007, 2016; Brush et al., 1980). Goodwin Island is located near Seaford, VA in the York River near the mouth of the Chesapeake Bay (Kirwan et al., 2016). Phillips Creek (Nassawadox, VA), Monie Bay (Venton, MD), and Moneystump Swamp (Golden Hill, MD) are located on the Delmarva Peninsula on the western shore of the Chesapeake Bay (Brinson et al., 1995; Kirwan et al., 2007). We sampled 89 P. taeda trees during early September 2019 (Table 1). Rhode River, Phillips Creek, Monie Bay, Goodwin Island, and Moneystump contain both nearshore forests that are flooded by seawater and higher elevation forests that are above the saline flood level. Within these sites, we sampled both the near shore seawater exposed forest and upland unexposed forests.

For this study, trees were sampled once during the growing season in late June 2019 at Beaver Creek and once in early September 2019 at Goodwin Island, Phillips Creek, Monie Bay, and Moneystump (Table 1). All the trees sampled in this study were estimated to be at mid-to late-growth stages, according to stem DBH threshold being greater than $13 \mathrm{~cm}$ (Blackwood et al., 2010; Shendryk et al., 2016).

\subsection{Tree Density, Tree Gas and Soil Porewater Sampling Method}

Average green-stem wood density measurements were recorded with an absolute density calibrated Rinntech Resistograph ${ }^{\circledast}$ R650-Sc (Rinn et al., 1996). Stem density was integrated across the stem at breast height. To measure stem concentrations of $\mathrm{pCH}_{4}$ and $\mathrm{pCO}_{2}$, we followed a similar protocol to that of Covey et al. (2012). Individual trees were cored with a 12-mm Haglof increment borer in which a stainless-steel pipe $(0.493$ " [12.5 mm] inner diameter and 43/64" outer diameter [17.06 mm]) was inserted with a rubber septum seal (Suba Seal ${ }^{\circledast}$ ) equipped for repeated gas sampling. Tree stem greenhouse gas samples were extracted at breast height via gas-tight syringe and needle $(25 \mathrm{ml})$. Stem $\mathrm{O}_{2}$ was measured with a Fire Sting $\mathrm{O}_{2}$ Optimal Oxygen Meter (Pyroscience, Bremen, Germany). Stem $\mathrm{O}_{2}$ saturation was normalized to atmospheric $\mathrm{O}_{2}(20.95 \%)$.

We followed the methodology from Ward et al. (2019) to measure $\mathrm{CH}_{4}$ and $\mathrm{CO}_{2}$ concentrations in the soil porewater at each site, using a headspace extraction method with porewater from the soil. A $60-\mathrm{cm}$ long, 3.175-mm-diameter stainless steel probe (M.H.E. Products Push Point Research Samplers) with small openings at the tip was inserted into three random locations within at each plot. A 60-mL syringe with a two-way Luer-lock valve was then used to draw out $20 \mathrm{~mL}$ of porewater from the soil probe. We used an additional syringe and a three-way Luer-lock valve to transfer $40 \mathrm{~mL}$ of pure $\mathrm{N}_{2}$ gas to the sampling syringe. The syringe was shaken for approximately $2 \mathrm{~min}$ to equilibrate the gases in the water sample, allowed to settle, and then $40 \mathrm{~mL}$ of the headspace was removed in the second $60-\mathrm{mL}$ syringe. Roughly $100 \mathrm{~mL}$ of porewater 
was collected prior to GHG sampling to rinse the sampling probe and discard initial water with high turbidity. Samples were collected immediately after this rinse step. Rinse steps occurred over $3 x$ the volume of the total porewater collection volume. Using the same sampling probe, we also measured porewater salinity, temperature, and dissolved oxygen using a YSI Pro Plus multiparameter sonde. In sites where porewaters were unable to be extracted, a $60-\mathrm{mL}$ gas sample was taken through the soil probe and soil oxygen was measured with the Fire Sting $\mathrm{GO}_{2}$ Optimal Oxygen Meter in the top $7 \mathrm{~cm}$ of soil.

Gas samples were collected into preevacuated glass vials and taken back to the lab for storage and analysis. Although gas samples were stored in gas tight vials, sample storage did not exceed 2-weeks from collection to analysis. Following the protocol described in Ward et al. (2019), gas samples were analyzed for the partial pressure of $\mathrm{CO}_{2}$ and $\mathrm{CH}_{4}$ (i.e., pGHG) by direct injection into a Picarro G2508 Cavity Ring-Down Spectrometer with a flow limiter installed on the inlet to reduce gas flow rates. Samples were diluted with $\mathrm{N}_{2}$ when GHG levels were above the instrument's threshold. All concentration values are reported in $\mu$ mol per liter of dry air $\left(\mu \mathrm{mol} \mathrm{L}{ }^{-1}\right)$. Porewater GHG values were corrected for dilution during headspace extraction and subsequent dilution prior to analysis based on the common gas law. Porewater gas concentrations were corrected for dissolution of gas in the water by converting to $\mu \mathrm{mol} \mathrm{L}{ }^{-1}$ with Henry's law using temperature- and salinity-dependent coefficients (Wanninkhof, 2014):

$$
\operatorname{In} \beta=\mathrm{A}_{1}+\mathrm{A}_{2} *(100 / \mathrm{T})+\mathrm{A}_{3} * \operatorname{In}(\mathrm{T} / 100)+\mathrm{S} *\left[\mathrm{~B}_{1}+\mathrm{B}_{2} *(\mathrm{~T} / 100)+\mathrm{B}_{3} *(\mathrm{~T} / 100)^{2}\right]
$$

where $\beta$ is the dimensionless Bunsen solubility coefficient, $\mathrm{T}$ is the temperature in ${ }^{\circ} \mathrm{Kelvin}$, and $\mathrm{S}$ is the salinity in parts per thousand (or practical salinity units). $A_{1}, A_{2}, A_{3}, B_{1}, B_{2}$, and $B_{3}$ are gas-specific coefficients reported in Wanninkhof (2014).

\subsection{Seawater Exposure Identification}

Seawater exposure was assigned qualitatively in the field via visual identification of individual trees in the flooded zone, and quantitatively in the lab via measurements of the concentration of porewater salinity in porewater. We identified trees in higher elevations (distal to shoreline), as locations that do not experience frequent seawater inundation events. Soil salinity, soil $\mathrm{O}_{2}$, soil $\mathrm{CO}_{2}$, and soil $\mathrm{CH}_{4}$ were measured at the plot level for each site. Trees located within a tidal flood zone plots, with saline porewaters higher than 0.10 (psu), were characterized as seawater exposed $(n=74)$. Trees classified as unexposed to seawater $(n=33)$, could however include disturbances outside of the scope of this study (e.g., pest infestation, nutrient enrichment, etc.) (Table 1).

\subsection{Statistical Analysis}

All significant thresholds were set to $\mathrm{p}<0.05$ and adjusted using Benjamini-Hochberg $\mathrm{p}$-value correction, with a confidence interval of $95 \%$. Wilcoxon signed-rank tests and Spearman linear relationships were tested between groups, where groups consisted of flooding type (seawater exposure) and tree survival (living or dying), defined by canopy cover (W. Wang et al., 2019). Factorial analysis of mixed data types (FAMD) was used to explore unique data clusters based upon input variables (including both numerical and categorical

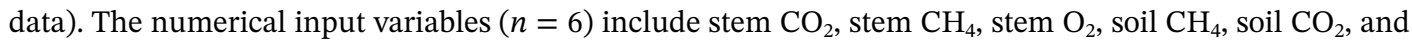
soil $\mathrm{O}_{2}$. The two categorical variables are seawater exposure and tree survival. Nonmetric multidimensional scaling with Euclidean distances was used to ordinate variables from the FAMD in 2-dimensional space $(k=2)$. Twenty random restarts were used to find a solution for the Euclidean distances along two axes. Bootstrapping with 999 permutations was used for group significance tests $(p<0.01)$. Homogeneity of the multivariant data was tested using analysis of variance for the output distances $(p=0.60)$. Both numerical and categorical data used for interpretation in this manuscript can be found in Norwood (2020).

The $\mathrm{R}$ packages used for data interpretation are freely available in $\mathrm{R}$ package version 0.8.3 and $\mathrm{R}$ 3.5.2 (RStudio Team, 2017). Original and adapted $\mathrm{R}$ codes used to run statistics and make figures are found in Table S1. All statistical tests were performed using R version 3.5.2 (RStudio Team, 2017); ggplot2 version 3.2.1 was used to make Figures 3-5 (Wickham et al., ). Factorial analysis of mixed data was performed with the factoextra R package version 1.0.5 (Kassambara \& Mundt, 2017). Nonmetric multidimensional scaling was performed with the vegan package 2.5-6 (Oksanen et al., 2019). 


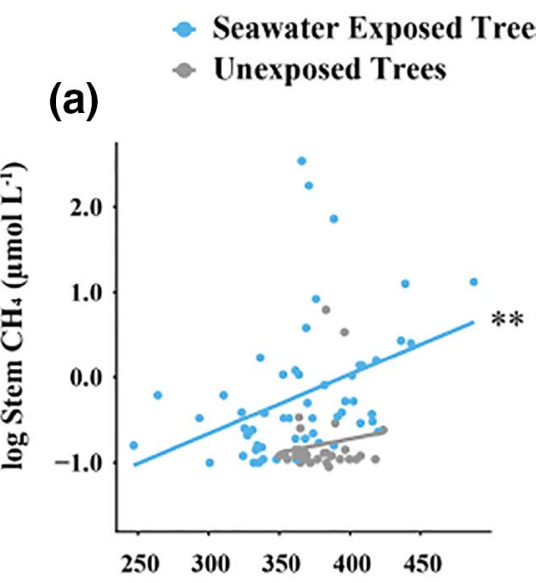

(b)

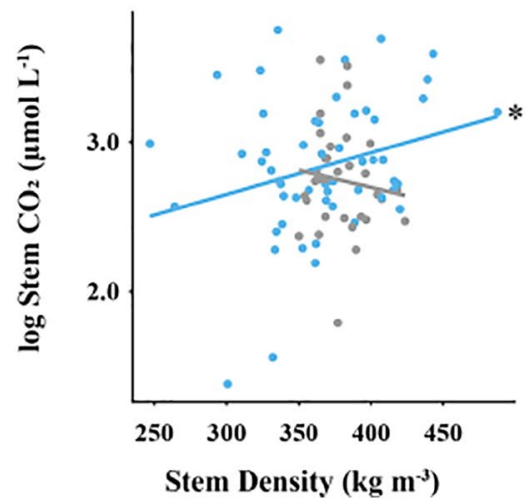

(c)

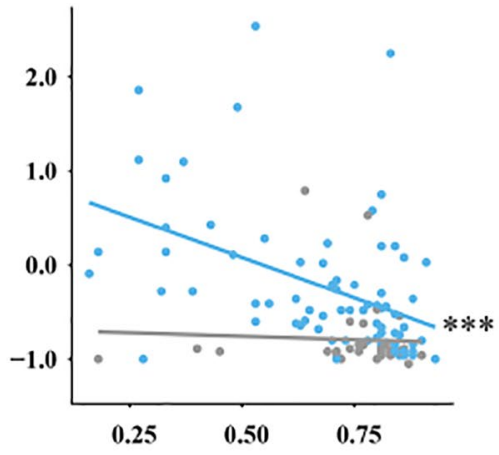

(d)

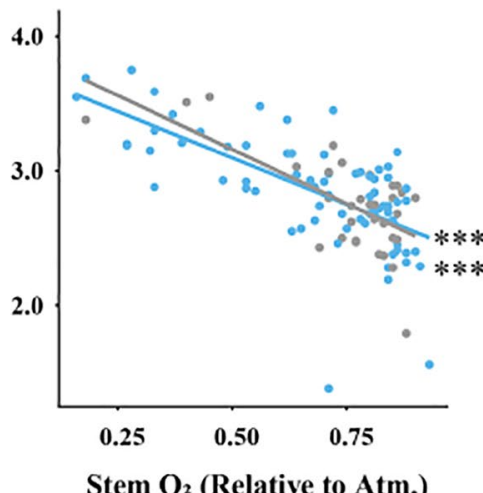

Living Trees

Dying Trees

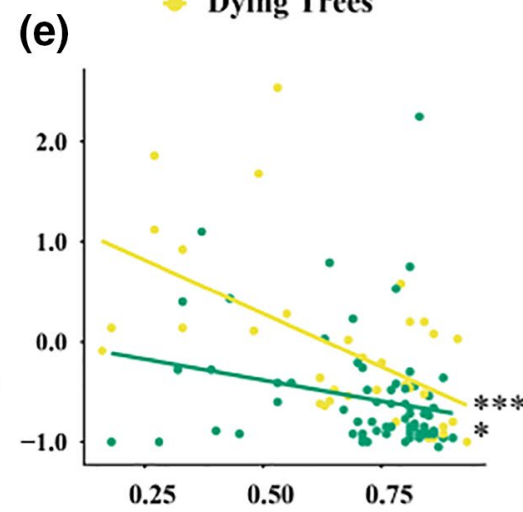

(f)

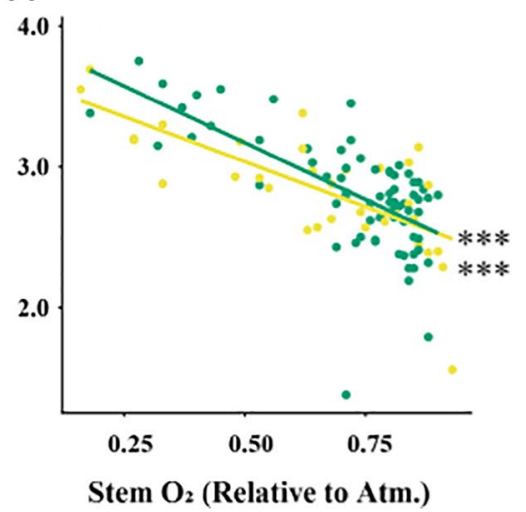

Figure 3. Scatterplots of tree stem $\log \mathrm{CH}_{4}\left(\mu \mathrm{mol} \mathrm{L} \mathrm{L}^{-1}\right)$ and stem $\log \mathrm{CO}_{2}\left(\mu \mathrm{mol} \mathrm{L} \mathrm{L}^{-1}\right)$ compared to average stem wood density $\left(\mathrm{kg} \mathrm{m} \mathrm{m}^{-3}\right)(\mathrm{A} \& \mathrm{~B}$, respectively) and stem $\mathrm{O}_{2}$ (C-F, respectively). Stem $\mathrm{O}_{2}$ is normalized to atmospheric $\mathrm{O}_{2}(20.95 \%)$. Data is grouped by seawater exposure (a)-(d) and tree survival (e) \& (f). Note Table 4 for significance statistics within the $95 \%$ confidence interval represented by *.

\section{Results}

\subsection{Tree and Soil Mean Statistics}

Mean stem wood density, stem $\mathrm{CH}_{4}$, stem $\mathrm{CO}_{2}$ and stem $\mathrm{O}_{2}$ was significantly different across the three different species (Table 2). P. sitchensis had significantly higher stem wood density, stem $\mathrm{CH}_{4}$, and significantly lower stem $\mathrm{O}_{2}$ compared to the other two tree species (Table 2). Mean stem $\mathrm{CH}_{4}$ was significantly higher for seawater exposed trees and dying trees (Table 2). Mean soil salinity, soil $\mathrm{CH}_{4}$, soil $\mathrm{CO}_{2}$ and soil $\mathrm{O}_{2}$ were significantly different for exposure type and tree survival; with seawater exposure and dying trees experiencing higher soil salinity, soil $\mathrm{CH}_{4}$, soil $\mathrm{CO}_{2}$ and lower soil $\mathrm{O}_{2}$ (Table 3).

\subsection{Correlation Between Stem Wood Density, Stem GHGs, and Stem $\mathrm{O}_{2}$}

Seawater exposed trees had a significant positive linear relationship between stem $\mathrm{CH}_{4}$ and stem wood density (Figure 3a \& Table 3). Similarly, seawater exposed trees had a significant positive linear relationship between stem $\mathrm{CO}_{2}$ and stem density (Figure $3 \mathrm{~b} \&$ Table 3). The linear relationship of both stem $\mathrm{CH}_{4}$ and stem $\mathrm{CO}_{2}$ has a significant negative linear relationship with stem $\mathrm{O}_{2}$ for seawater exposed trees (Figures $3 \mathrm{c}$ and $3 \mathrm{~d}$ \& Table 3); with a significant negative linear relationship between stem $\mathrm{CO}_{2}$ and $\mathrm{O}_{2}$ (Figure $3 \mathrm{~d} \&$ Table 3 ).

Tree survival (living or dying) did not have a significant effect on the relationship between stem GHGs $\left(\mathrm{CH}_{4}\right.$ or $\mathrm{CO}_{2}$ ) and stem wood density. Living and dying trees had a significant negative linear relationship between stem $\mathrm{CH}_{4}$ and stem $\mathrm{O}_{2}$; while only living trees had a significant negative linear relationship between stem $\mathrm{CO}_{2}$ and stem $\mathrm{O}_{2}$ (Figures 3e and $3 \mathrm{f} \&$ Table 3). 
(a)

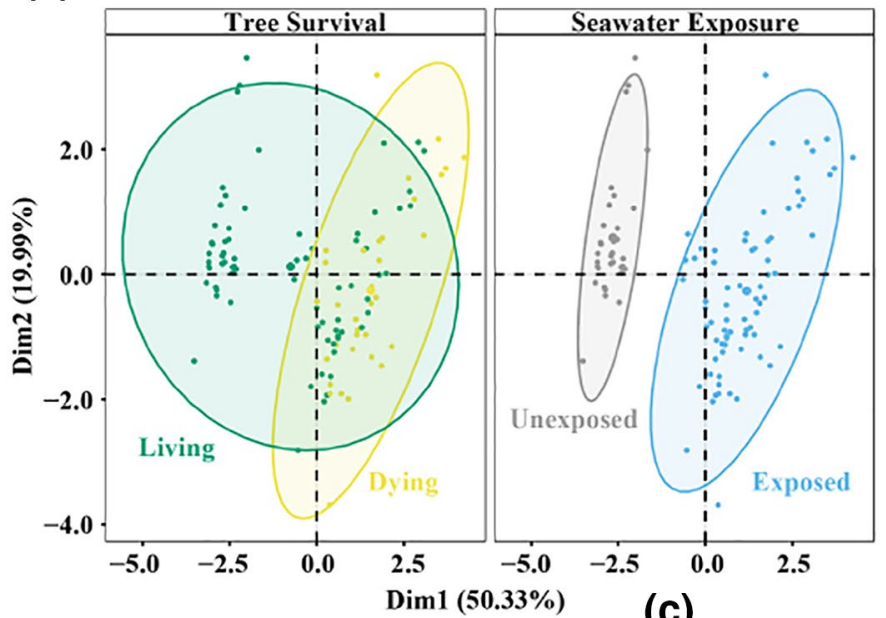

(b)
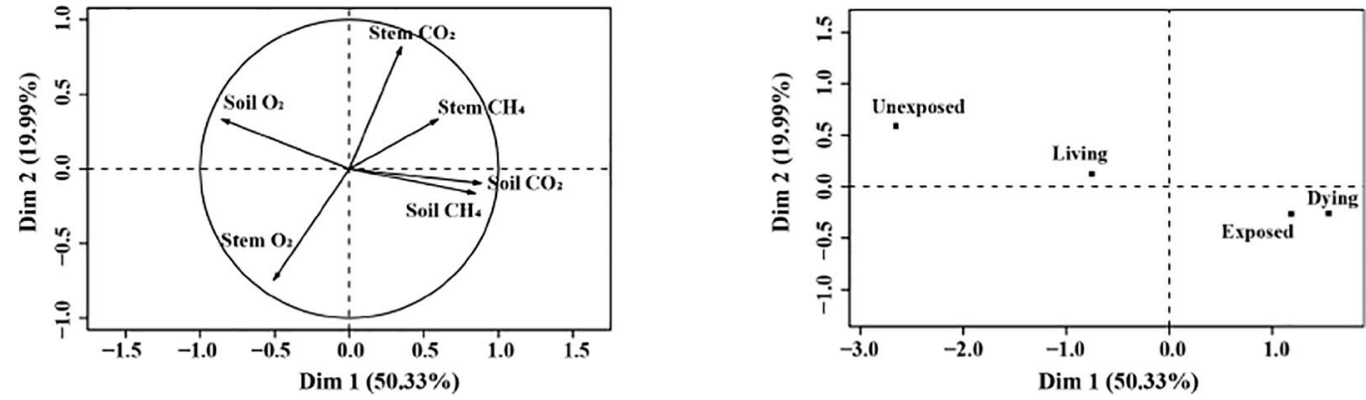

Figure 4. Factorial Analysis of Mixed Data Map (a) and distribution of quantitative variables (b). The quantitative variables include $\log$ stem $\mathrm{CO}_{2}\left(\mu \mathrm{mol} \mathrm{L}^{-1}\right)$, $\log$ stem $\mathrm{CH}_{4}\left(\mu \mathrm{mol} \mathrm{L}{ }^{-1}\right)$, stem $\mathrm{O}_{2}$, soil $\mathrm{O}_{2}$, log soil $\mathrm{CH}_{4}\left(\mu \mathrm{mol} \mathrm{L}{ }^{-1}\right)$, and $\log$ soil $\mathrm{CO}_{2}\left(\mu \mathrm{mol} \mathrm{L}{ }^{-1}\right)$. The categorical variables (c) include tree survival (living or dying) and seawater exposure (exposed or unexposed).

\subsection{Factorial Analysis of Mixed Data and Nonmetric Multidimensional Scaling}

Factorial Analysis of Mixed Data (FAMD) was performed to evaluate how both qualitative information (i.e., tree survival [living or dying] and seawater exposure [exposed or unexposed]) and quantitative data (i.e., stem $\mathrm{CO}_{2}$, stem $\mathrm{CH}_{4}$, stem $\mathrm{O}_{2}$, soil $\mathrm{CH}_{4}$, soil $\mathrm{CO}_{2}$, and soil $\mathrm{O}_{2}$ ) interact and cluster based on their main drivers (Figures $4 \mathrm{a}-4 \mathrm{c}$ ). Dimensions one and two explained $70.32 \%$ of the variability in this data set (Figures $4 \mathrm{a}-4 \mathrm{c}$ ). Dimension one explained $50.33 \%$ of the variation in our data, and was associated with soil $\mathrm{O}_{2}$,

Effects of Seawater Exposure on Tree \& Soil GHG Accumulation

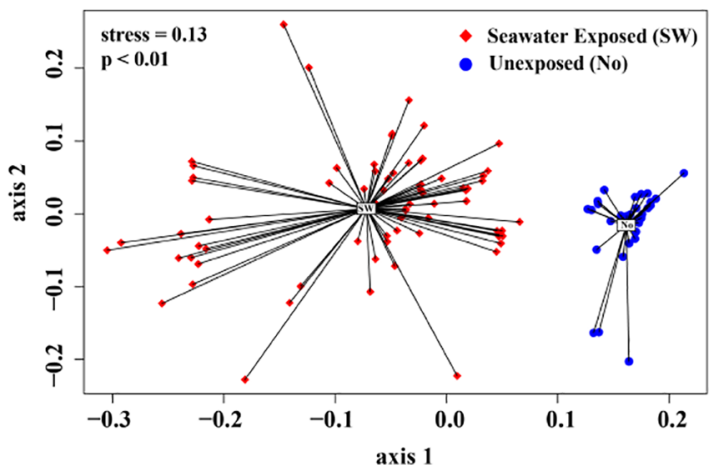

Figure 5. Nonmetric multidimensional scaling (NMDS) of quantitative variables and qualitative variables used in FAMD. soil $\mathrm{CH}_{4}$, and soil $\mathrm{CO}_{2}$; with soil $\mathrm{O}_{2}$ having inverse relationship with soil GHGs along dimension one (Figure 4b). Dimension two explained 19.99\% of the variation in our data, and was associated with stem $\mathrm{O}_{2}$, stem $\mathrm{CH}_{4}$, and stem $\mathrm{CO}_{2}$; with stem $\mathrm{O}_{2}$ having inverse relationship with stem GHGs along dimension two (Figure 4b). The categorical variables - tree survival and seawater exposure-were spread along dimensions one and two; with dying trees and seawater exposed trees clustering separately from unexposed-living trees (Figure 4c). Nonmetric multidimensional scaling (NMDS) was used to interpret multivariate data from the FAMD (i.e., seawater exposure, tree survival, stem $\mathrm{CO}_{2}$, stem $\mathrm{CH}_{4}$, stem $\mathrm{O}_{2}$, soil $\mathrm{CO}_{2}$, soil $\mathrm{CH}_{4}$, and soil $\mathrm{O}_{2}$ ). The NMDS model illustrates that there is a statistically significant difference between the seawater exposed gymnosperm trees and unexposed gymnosperm trees (Figure 5). The stress for the plot of variables in two-dimensions was 0.13 (Figure 5). Seawater exposure was a significant variable for stem and soil gases $\left(\mathrm{CH}_{4}, \mathrm{CO}_{2}\right.$, and $\left.\mathrm{O}_{2}[p<0.01]\right)$; while tree survival was not a significant variable $(p=0.18)$ (Figure 5). 
Table 2

Mean Comparison for Stem Wood Density $\left(\mathrm{kg} \mathrm{m}^{-3}\right)$, Stem $\mathrm{O}_{2}$ (Relative to Atmospheric [20.95]), Stem $\mathrm{CH}_{4}\left(\mu \mathrm{mol} \mathrm{L}{ }^{-1}\right.$ ), and Stem $\mathrm{CO}_{2}\left(\mu \mathrm{mol} \mathrm{L}{ }^{-1}\right)$ for Tree Species, Seawater Exposure (Exposed or Unexposed), and Tree Survival (Living or Dying) (Mean \pm Standard Error)

\begin{tabular}{|c|c|c|c|c|}
\hline Type & Density $\left(\mathrm{kg} \mathrm{m}^{-3}\right)$ & Stem $\mathrm{O}_{2}$ (Rel.) & Stem $\mathrm{CH}_{4}\left(\mu \mathrm{mol} \mathrm{L}{ }^{-1}\right)$ & Stem $\mathrm{CO}_{2}\left(\mu \mathrm{mol} \mathrm{L}{ }^{-1}\right)$ \\
\hline P. sitchensis $\left(n_{\mathrm{s}}=12\right)$ & $413 \pm 9.30$ & $0.33 \pm 0.03$ & $9.69 \pm 5.83$ & $2,214 \pm 372$ \\
\hline T. heterophylla $\left(n_{\mathrm{s}}=6\right)$ & $347 \pm 14.8$ & $0.43 \pm 0.08$ & $0.20 \pm 0.05$ & $3,430 \pm 462$ \\
\hline P. taeda & $366 \pm 3.54$ & $0.77 \pm 0.01$ & $7.01 \pm 4.41$ & $634 \pm 42.7$ \\
\hline Species & $\mathrm{H}=18.4, p<0.001$ & $\mathrm{H}=41.3, p<0.001$ & $\mathrm{H}=20.9, p<0.001$ & $\mathrm{H}=20.9, p<0.001$ \\
\hline Exposed & $366 \pm 5.32$ & $0.68 \pm 0.02$ & $9.83 \pm 5.35$ & $1,049 \pm 123$ \\
\hline Unexposed & $378 \pm 3.20$ & $0.76 \pm 0.03$ & $0.42 \pm 0.21$ & $786 \pm 141$ \\
\hline Exposure & $\mathrm{H}=0.37, p=0.54$ & $\mathrm{H}=1.33, p=0.25$ & $\mathrm{H}=29.2, p<0.001$ & $\mathrm{H}=0.29, p=0.59$ \\
\hline Living & $370 \pm 3.68$ & $0.73 \pm 0.02$ & $3.17 \pm 2.50$ & $956 \pm 118$ \\
\hline Dying & $373 \pm 8.42$ & $0.66 \pm 0.04$ & $14.6 \pm 3.58$ & $991 \pm 166$ \\
\hline Survival & $\mathrm{H}=0.35, p=0.56$ & $\mathrm{H}=1.71, p=0.19$ & $\mathrm{H}=15.1, p<0.001$ & $\mathrm{H}=0.15, p=0.70$ \\
\hline
\end{tabular}

\section{Discussion}

Trees may play an important role in global climate regulation by transporting greenhouse gases such as methane $\left(\mathrm{CH}_{4}\right)$ and carbon dioxide $\left(\mathrm{CO}_{2}\right)$, into the atmosphere. As seawater exposure only began in the last few decades (or less) for trees located within the coastal forest sites sampled in this study, trees were likely not well adapted to seawater conditions. Increased stem $\mathrm{CH}_{4}$ is significantly correlated to increased wood density in seawater exposed trees (i.e., positive linear relationship), which may be linked to increased stem water content and decreased tracheid size increasing the gas diffusion barrier between internal stem $\mathrm{CH}_{4}$ and atmospheric $\mathrm{CH}_{4}$ (Ståhl, 1988) (Figure 3). Furthermore, seawater exposure is linked to tree survival (W. Wang et al., 2019) and increased stem $\mathrm{CH}_{4}$ concentration, with higher soil salinities associated with decreased tree survival and increased soil $\mathrm{CH}_{4}$ (i.e., positive linear relationship, Figure 1). Dying trees were significantly linked to high salinity and low $\mathrm{O}_{2}$ soils (Table 3), highlighting seawater flooding impacts on coastal forest soils, tree survival, and GHGs. The compounding effects of seawater exposure on coastal forests GHG exchange are likely linked to both soil and tree eco-physical mechanisms; such as soil-tree-stem gas diffusion barriers and soil redox environments (Covey \& Megonigal, 2019; Megonigal, 2020; Warner et al., 2017).

A consistent pattern that emerged from this broad survey of stem gas concentrations was the negative relationship between stem $\mathrm{O}_{2}$ and stem GHGs $\left(\mathrm{CO}_{2}\right.$ and $\left.\mathrm{CH}_{4}\right)$. We interpret this pattern to be a consequence of physical limitations to gas diffusion rates arising from wood anatomical features that affect the volume and connectivity of intercellular spaces, and the fraction of intercellular spaces filled with either water or air. Although stem gas abundance has been studied in tree stems (Hietala et al., 2015; Teskey et al., 2008), to our knowledge, this is the first study to examine the relationship of internal stem $\mathrm{CH}_{4}$ and $\mathrm{O}_{2}$ abundance in seawater exposed gymnosperm trees. Factors that decrease the diffusion of gases sourced from inside the stem- $\mathrm{CO}_{2}$ and $\mathrm{CH}_{4}$-will slow the efflux of these gases to the atmosphere and thereby increase their stem concentration. These same factors will slow the diffusion of gases sourced from the atmosphere- $-\mathrm{O}_{2}-$ and thereby lower their stem concentration. This is consistent with the observation that tree stem emissions of soil-sourced radon peaked during daylight, when stem water content was at its daily minimum (Megonigal et al., 2020). Because radon is neither produced or destroyed in soils or tree stems, we concluded that stem water content was regulating stem emissions of radon, $\mathrm{CO}_{2}$, and $\mathrm{CH}_{4}$, all of which were positively correlated in angiosperm trees (Megonigal et al., 2020). Our observations indicate that stem water content and/or wood structure/anatomy may also regulate $\mathrm{O}_{2}$ diffusion into gymnosperm stems, with consequences for the potential of the stem to support conditions for methanogenesis and methanotrophy.

Stem $\mathrm{O}_{2}$ concentrations varied widely from anoxic to hypoxic to fully oxic, a pattern that held across all categories of trees (Figure 3). While this is consistent with previous observations of low stem $\mathrm{O}_{2}$ concentra- 
Table 3

Mean Comparison for Soil $\mathrm{O}_{2}$ (Relative to Atmospheric [20.95]), Soil $\mathrm{CH}_{4}\left(\mu \mathrm{mol} \mathrm{L}{ }^{-1}\right)$, Soil $\mathrm{CO}_{2}\left(\mu m o l L^{-1}\right)$, and Soil Salinity (Psu) Seawater Exposure (Exposed or Unexposed) and Tree Survival (Living or Dying) (Mean \pm Standard Error)

\begin{tabular}{|c|c|c|c|c|}
\hline Type & Soil $\mathrm{O}_{2}$ (Rel.) & Soil $\mathrm{CH}_{4}\left(\mu \mathrm{mol} \mathrm{L}^{-1}\right)$ & Soil $\mathrm{CO}_{2}\left(\mu \mathrm{mol} \mathrm{L}{ }^{-1}\right)$ & Soil salinity (psu) \\
\hline Exposed & $0.31 \pm 0.04\left(n_{\mathrm{s}}=32\right)$ & $58.1 \pm 17.6\left(n_{\mathrm{s}}=32\right)$ & $722 \pm 65.6\left(n_{\mathrm{s}}=32\right)$ & $\begin{array}{r}11.3 \pm 0.83 \\
\left(n_{\mathrm{s}}=32\right)\end{array}$ \\
\hline Unexposed & $0.95 \pm 0.01\left(n_{\mathrm{s}}=6\right)$ & $0.14 \pm 0.03\left(n_{\mathrm{s}}=6\right)$ & $109 \pm 25.5\left(n_{\mathrm{s}}=6\right)$ & $0.00 \pm 0.00\left(n_{\mathrm{s}}=6\right)$ \\
\hline Exposure $(\mathrm{df}=1)$ & $\mathrm{H}=49.6, p<0.001$ & $\mathrm{H}=50.3, p<0.001$ & $\mathrm{H}=56.2, p<0.001$ & $\mathrm{H}=69.6, p<0.001$ \\
\hline Living & $0.60 \pm 0.08\left(n_{\mathrm{s}}=21\right)$ & $32.1 \pm 17.2\left(n_{\mathrm{s}}=21\right)$ & $441 \pm 90.1\left(n_{\mathrm{s}}=21\right)$ & $\begin{array}{r}6.00 \pm 1.42 \\
\quad\left(n_{\mathrm{s}}=21\right)\end{array}$ \\
\hline Dying & $0.32 \pm 0.06\left(n_{\mathrm{s}}=17\right)$ & $56.9 \pm 24.7\left(n_{\mathrm{s}}=17\right)$ & $722 \pm 91.2\left(n_{\mathrm{s}}=17\right)$ & $\begin{array}{r}11.6 \pm 1.15 \\
\left(n_{\mathrm{s}}=17\right)\end{array}$ \\
\hline Survival (df = 1) & $\mathrm{H}=10.3, p<0.01$ & $\mathrm{H}=9.95, p<0.01$ & $\mathrm{H}=14.4, p<0.001$ & $\mathrm{H}=17.6, p<0.001$ \\
\hline
\end{tabular}

tions (Baxter et al.,; Covey \& Megonigal, 2019; Mugnai \& Mancuso, 2010 and references therein), we show that trees subjected to seawater exposure also support a wide range of stem redox environments. Previous studies found that lowering stem $\mathrm{O}_{2}$ from $10 \%$ to $5 \%$ (v/v) resulted in a $25 \%$ reduction in respiration (Spicer \& Holbrook, 2007), indicating that stem redox environments may control stem physiological function. Although we did not directly measure soil redox in this study, it is likely that seawater exposed trees and unexposed trees are rooted in a range of redox environments that may influence stem and soil gas exchange. This suggests that one of the most robust predictors of methanogenesis $-\mathrm{O}_{2}$ content - cannot be predicted from the categories of tree condition used here, although tree $\mathrm{O}_{2}$ was a good predictor of stem $\mathrm{CH}_{4}$ and $\mathrm{CO}_{2}$.

Seawater exposure has a significant effect on the amount of $\mathrm{CH}_{4}$ accumulated within tree stems (Table 2). Small differences in linear relationships between stem $\mathrm{CO}_{2}$ versus stem $\mathrm{O}_{2}$ for seawater exposure (Figure 3d), suggests that stem $\mathrm{CO}_{2}$ is tightly coupled to $\mathrm{O}_{2}$ concentrations within the stem. Teskey and Mcguire (2007) found that $34 \%$ of $\mathrm{CO}_{2}$ released by respiring cells within the xylem remained within the tree stem, while a portion of efflux $\mathrm{CO}_{2}$ from the stem to the atmosphere originated in the root system (Teskey \& Mcguire, 2007). This indicates that stem $\mathrm{CO}_{2}$ increase is coupled to both soil and stem $\mathrm{CO}_{2}$ pools and that stem $\mathrm{CO}_{2}$ increase is likely governed by physiological tree mechanisms, such as internal stem respiration rates (Ryan et al., 1992).

Seawater exposure significantly increased stem $\mathrm{CH}_{4}$, soil $\mathrm{CH}_{4}$, soil $\mathrm{CO}_{2}$, and soil salinity. One explanation for this pattern is that high levels of soil water content lead to high levels of stem water content, which in turn cause low rates of gas diffusion out of both the soils and tree stems where they are produced. Furthermore, trees growing in wet soils could be venting soil produced $\mathrm{CH}_{4}$ from deeper soil layers, thereby bypassing zones of $\mathrm{CH}_{4}$ oxidation in shallower soil horizons (Gauci et al., 2019). Higher stem and soil $\mathrm{CH}_{4}$ in seawater exposed environments compared to unexposed environments suggests that this can occur even in locations where soil $\mathrm{CH}_{4}$ fluxes are expected to be low due to sulfate abundance (Poffenbarger et al., 2011; Seyfferth et al., 2020). Previous studies have shown that rotting wood has similar magnitudes of $\mathrm{CH}_{4}$ emissions as local soils, suggesting that buried rotting wood could switch soil $\mathrm{CH}_{4}$ oxidation to soil $\mathrm{CH}_{4}$ efflux (Warner et al., 2017). This could be an alternative explanation to high stem and soil $\mathrm{CH}_{4}$ in seawater exposed trees where trees are acting as a conduit for methylotrophic methanogenesis deeper in soils and transported to the tree stem via soil-root-stem pathway.

Stem variables show an orthogonal relation with soil variables, indicating that stem and soil variables are related to both seawater exposure and tree survival (Figure 4). Living and unexposed trees were strongly associated with soil and stem $\mathrm{O}_{2}$ (Figure 4), while tree stem and soil GHGs had a strong orthogonal relationship with dying and seawater exposed trees (Figure 4). This is likely related to lower rates of soil methanogenesis in unexposed soils, but possibly also due to an increase in sulfate reduction within seawater exposed topsoil and sulfate uptake by tree roots located within soil rhizome layers (Ahmed et al., 2019; Rennenberg, 1999). Within anerobic environments, where $\mathrm{SO}_{4}{ }^{2-}$ and nitrate $\left(\mathrm{NO}_{3}{ }^{-}\right)$are limited, the complete mineralization 
Table 4

Mean Correlation Statistics for the Linear Relationship Between Average Stem Wood Density $\left(\mathrm{kg} \mathrm{m}^{-3}\right), \mathrm{Stem} \mathrm{O}_{2}($ Relative to Atmospheric [20.95]), Log Stem $\mathrm{CH}_{4}\left(\mu \mathrm{mol} \mathrm{L}{ }^{-1}\right), \log$ Stem $\mathrm{CO}_{2}\left(\mu \mathrm{mol} \mathrm{L}{ }^{-1}\right)$ for Seawater Exposure (Exposed and Unexposed) and Tree Survival (Living or Dying). p-values are From Spearman Correlations

\begin{tabular}{lcccc}
\hline Treatment & Stem density: Stem $\mathrm{CH}_{4}$ & Stem density: Stem $\mathrm{CO}_{2}$ & ${\text { Stem } \mathrm{CH}_{4}: \mathrm{Stem} \mathrm{O}_{2}}^{\text {Stem }_{2} \text { : Stem } \mathrm{O}_{2}}$ \\
\hline Exposed $(\mathrm{df}=72)$ & $\mathrm{R}^{2}=0.16, p<0.01$ & $\mathrm{R}^{2}=0.08, p<0.05$ & $\mathrm{R}^{2}=0.20, p<0.001$ & $\mathrm{R}^{2}=0.44, p<0.001$ \\
Unexposed $(\mathrm{df}=31)$ & $\mathrm{R}^{2}=0.02, p=0.41$ & $\mathrm{R}^{2}=0.01, p=0.51$ & $\mathrm{R}^{2}=0.01, p=0.76$ & $\mathrm{R}^{2}=0.46, p<0.001$ \\
Living $(\mathrm{df}=70)$ & $\mathrm{R}^{2}=0.05, p=0.09$ & $\mathrm{R}^{2}=0.02, p=0.35$ & $\mathrm{R}^{2}=0.06, p=0.05$ & $\mathrm{R}^{2}=0.44, p<0.001$ \\
Dying $(\mathrm{df}=33)$ & $\mathrm{R}^{2}=0.11, p=0.10$ & $\mathrm{R}^{2}=0.08, p=0.15$ & $\mathrm{R}^{2}=0.32, p<0.001$ & $\mathrm{R}^{2}=0.51, p<0.001$ \\
\hline
\end{tabular}

of organic matter occurs via methanogenic fermentation (Le Mer \& Roger, 2001; Megonigal et al., 2003). The link between soil $\mathrm{CH}_{4}$ and soil $\mathrm{O}_{2}$ is attributed to the soil redox environment, which reflects the favored substrates used for coupled reduction and oxidation processes in soil biogeochemical cycles. When soil $\mathrm{CH}_{4}$ production is favored there is typically a depletion of other electron donors such as $\mathrm{O}_{2}, \mathrm{Fe}^{3+}$, $\mathrm{NO}^{3-}$, and $\mathrm{SO}_{4}{ }^{2-}$. In chronically seawater exposed environments (e.g., marshes), $\mathrm{SO}_{4}{ }^{2-}$ is a more thermodynamically favorable electron donor, however this is not straight forward in terms of sporadic seawater exposed where flooding occurs in association to storm events and extreme high tides (Osman, 2013).

We found that seawater exposure significantly affects the abundance of both soil and stem GHGs, with distinct and significant differences in the effects of seawater exposure on soil and tree GHGs (Figure 5). Further, seawater exposure significantly decreases tree survival, with increased soil salinities significantly correlated to tree survival (Table 2). Disturbances that increase seawater or freshwater flooding have the potential to increase stem $\mathrm{CH}_{4}$ emissions to the atmosphere through increased emissions from soil produced $\mathrm{CH}_{4}$, although major controls on stem gas emissions (i.e., gas diffusion barriers), may ultimately govern the magnitude of stem $\mathrm{CH}_{4}$ emissions. Increased transport and emissions of soil gas through tree stems is caused by a steeper soil-atmosphere $\mathrm{CH}_{4}$ concentration gradient and represents an increase in soil-tree-atmosphere coupling (Covey \& Megonigal, 2019). Increased tree stem $\mathrm{CH}_{4}$ concentrations in flooded environments may potentially increase the magnitude of stem $\mathrm{CH}_{4}$ fluxes to the atmosphere from forest ecosystems (Pangala et al., 2013).

\section{Conclusion}

We found that seawater exposure is associated with increased soil and stem $\mathrm{CH}_{4}$ and decreased tree survival. Increased stem $\mathrm{CH}_{4}$ concentrations in response to coastal flooding suggests an increase in soil $\mathrm{CH}_{4}$ flux through stems, which would short-circuit soil $\mathrm{CH}_{4}$ oxidation and contribute to an overall increase in $\mathrm{CH}_{4}$ emissions from the coastal forest ecosystems such as those impacted by sea level rise (Figure 1). Tree stem wood density may be a governing mechanism on the accumulation of greenhouse gases within tree stems, with seawater exposed trees containing significantly higher concentrations of stem $\mathrm{CH}_{4}$ that is significantly correlated with increased wood density. Our results are based entirely on observational data, and thus these conclusions are tentative correlations only; confirmation and attribution of causation will require future testing in manipulative experiments. Future identification of at-risk coastal forests that will experience seawater exposure, and quantification of stem $\mathrm{CH}_{4}$ emissions within coastal forests will aid in refinement of baseline coastal forest $\mathrm{CH}_{4}$ fluxes to the atmosphere.

\section{Data Availability Statement}

All data supporting the analyses and conclusions of this study are presented in the figures, tables, and supporting information of this manuscript. The data used in this manuscript can be found in Norwood, M. (2020), Coastal Forest Seawater Exposure Increases Stem Methane Concentration Manuscript Data, HydroShare, https://doi.org/10.4211/hs.17e9a223ffe64e768e6cb8b2a77c198d. 
Acknowledgments

The research described in this paper is part of the Open Call Initiative at the Pacific Northwest National Laboratory. It was conducted under the Laboratory Directed Research and Development Program at PNNL, a multiprogram national laboratory operated by Battelle for the U.S. Department of Energy. We thank the PNNL Marine Sciences Lab for access to the Sequim Bay field site. We thank Don Lentz, Hancock Timber Company, and WA Department of Fish \& Wildlife for access to the Beaver Creek field site. We thank Tyler Messerschmidt, Alex Smith, and Krystal Krygowski for aid in field campaigns.

\section{References}

Ahmed, S., Kayes, I., Shahriar, S. A., Kabir, M. M., Salam, M. A., \& Mukul, S. A. (2019). Global Journal of Environmental Science and Management Soil salinity and nutrients pattern along a distance gradient in coastal region. Global Journal of Environmental Science and Management, 6(1), 59-72. https://doi.org/10.22034/gjesm.2020.01.05

Barba, J., Bradford, M. A., Brewer, P. E., Bruhn, D., Covey, K., van Haren, J., et al. (2019). Methane emissions from tree stems: A new frontier in the global carbon cycle. New Phytologist, 222(1), 18-28. https://doi.org/10.1111/nph.15582

Blackwood, A., Kingsford, R., Nairn, L., \& Rayner, T. (2010). The effect of river red gum decline on woodland birds in the Macquarie Marshes. Sydney, Australia: The Australian Rivers and Wetlands Centre.

Bousquet, P., Ciais, P., Miller, J. B., Dlugokencky, E. J., Hauglustaine, D. A., Prigent, C., et al. (2006). Contribution of anthropogenic and natural sources to atmospheric methane variability. Nature, 443(7110), 439-443. https://doi.org/10.1038/nature05132

Bowden, R. D., Castro, M. S., Melillo, J. M., Steudler, P. A., \& Aber, J. D. (1993). Fluxes of greenhouse gases between soils and the atmosphere in a temperate forest following a simulated hurricane blowdown. Biogeochemistry, 21(2), 61-71.

Boyer, J. S., Wong, S. C., \& Farquhar, G. D. (1997). $\mathrm{CO}_{2}$ and water vapor exchange across leaf cuticle (epidermis) at various water potentials. Plant Physiology, 114(1), 185-191.

Bridgham, S. D., Cadillo-Quiroz, H., Keller, J. K., \& Zhuang, Q. (2013). Methane emissions from wetlands: Biogeochemical, microbial, and modeling perspectives from local to global scales. Global Change Biology, 19(5), 1325-1346. https://doi.org/10.1111/gcb.12131

Brinson, M. M., Christian, R. R., \& Blum, L. K. (1995). Multiple states in the sea-level induced transition from terrestrial forest to estuary. Estuaries, 18(4), 648-659. https://doi.org/10.2307/1352383

Brush, G. S., Lenk, C., \& Smith, J. (1980). The Natural Forests of Maryland: An Explanation of the Vegetation Map of Maryland. Ecological Monographs, 50(1), 77-92. http://dx.doi.org/10.2307/2937247

Carmichael, M. J., Bernhardt, E. S., Bräuer, S. L., \& Smith, W. K. (2014). The role of vegetation in methane flux to the atmosphere: Should vegetation be included as a distinct category in the global methane budget? Biogeochemistry, 119(1-3), 1-24. https://doi.org/10.1007/ s10533-014-9974-1

Cerasoli, S., McGuire, M. A., Faria, J., Mourato, M., Schmidt, M., Pereira, J. S., et al. (2009). $\mathrm{CO}_{2}$ efflux, $\mathrm{CO}_{2}$ concentration and photosynthetic refixation in stems of Eucalyptus globulus (Labill.). Journal of Experimental Botany, 60(1), 99-105. https://doi.org/10.1093/jxb/ ern272

Collin, M., \& Rasmuson, A. (1988). A comparison of gas diffusivity models for unsaturated porous media. Soil Science Society of America Journal, 52(6), 1559-1565.

Covey, K. R., \& Megonigal, J. P. (2019). Methane production and emissions in trees and forests. New Phytologist, 222(1), 35-51. https://doi. org $/ 10.1111 /$ nph.15624

Covey, K. R., Wood, S. A., Warren, R. J., Lee, X., \& Bradford, M. A. (2012). Elevated methane concentrations in trees of an upland forest. Geophysical Research Letters, 39(15). https://doi.org/10.1029/2012GL052361

Crowther, T. W., Glick, H. B., Covey, K. R., Bettigole, C., Maynard, D. S., Thomas, S. M., et al. (2015). Mapping tree density at a global scale. Nature, 525(7568), 201-205. https://doi.org/10.1038/nature14967

de Coninck, H., Revi, A., Babiker, M., Bertoldi, P., Buckeridge, M., Cartwright, A., et al. (2018). Chapter 4: Strengthening and implementing the global response. In: Global Warming of $1.5^{\circ} \mathrm{C}$ an IPCC special report on the impacts of global warming of $1.5^{\circ} \mathrm{C}$ above pre-industrial levels and related global greenhouse gas emission pathways, in the context of strengthening the global response to the threat of climate change. Intergovernmental Panel on Climate Change.

Dlugokencky, E. J., Nisbet, E. G., Fisher, R., \& Lowry, D. (2011). Global atmospheric methane: Budget, changes and dangers. Philosophical Transactions of the Royal Society A: Mathematical, Physical and Engineering Sciences, 369(1943), 2058-2072.

Fagherazzi, S., Anisfeld, S. C., Blum, L. K., Long, E. V., Feagin, R. A., Fernandes, A., et al. (2019). Sea level rise and the dynamics of the marsh-upland boundary. Frontiers in Environmental Science, 7, 25.

Fichtner, A., Von Oheimb, G., Härdtle, W., Wilken, C., \& Gutknecht, J. L. M. (2014). Effects of anthropogenic disturbances on soil microbial communities in oak forests persist for more than 100 years. Soil Biology and Biochemistry, 70, 79-87.

Gauci, V., Pangala, S. R., Enrich-Prast, A., Gedney, N., Stauffer, T., Figueiredo, V., \& Bastviken, D. (2019). Seasonal variability of tree methane emissions in the Central Amazon floodplain. AGUFM, 2019, B24B02.

Hadden, D., \& Grelle, A. (2016). Changing temperature response of respiration turns boreal forest from carbon sink into carbon source. Agricultural and Forest Meteorology, 223, 30-38.

Hietala, A. M., Dörsch, P., Kvaalen, H., \& Solheim, H. (2015). Carbon dioxide and methane formation in Norway spruce stems infected by white-rot fungi. Forests, 6(9), 3304-3325. https://doi.org/10.3390/f6093304

Kassambara, A., \& Mundt, F. (2017). Package 'factoextra. In A. Kassambara (Ed.), Extract and visualize the results of multivariate data analyses (Vol. 76).

King, G. (1997). Responses of atmospheric methane consumption by soils to global climate change. Global Change Biology, 3(4), 351-362.

Kirwan, M. L., \& Gedan, K. B. (2019). Sea-level driven land conversion and the formation of ghost forests. Nature Climate Change, 9(6), 450-457. https://doi.org/10.1038/s41558-019-0488-7

Kirwan, M. L., Kirwan, J. L., \& Copenheaver, C. A. (2007). Dynamics of an estuarine forest and its response to rising sea level. Journal of Coastal Research, 232, 457-463. https://doi.org/10.2112/04-0211.1

Kirwan, M. L., Walters, D. C., Reay, W. G., \& Carr, J. A. (2016). Sea level driven marsh expansion in a coupled model of marsh erosion and migration. Geophysical Research Letters, 43(9), 4366-4373. https://doi.org/10.1002/2016GL068507

Le Mer, J., \& Roger, P. (2001). Production, oxidation, emission and consumption of methane by soils: A review. European Journal of Soil Biology, 37(1), 25-50. https://doi.org/10.1016/S1164-5563(01)01067-6

Lin, T.-C., Hogan, J. A., \& Chang, C.-T. (2020). Tropical cyclone ecology: A scale-link perspective. Trends in Ecology \& Evolution, 35(7), 594-604. https://doi.org/10.1016/j.tree.2020.02.012

Machacova, K., Bäck, J., Vanhatalo, A., Halmeenmäki, E., Kolari, P., Mammarella, I., et al. (2016). Pinus sylvestris as a missing source of nitrous oxide and methane in boreal forest. Scientific Reports, 6(1). http://dx.doi.org/10.1038/srep23410

Mark, G. L., Dow, J. M., Kiely, P. D., Higgins, H., Haynes, J., Baysse, C., et al. (2005). Transcriptome profiling of bacterial responses to root exudates identifies genes involved in microbe-plant interactions. Proceedings of the National Academy of Sciences, 102(48), $17454-17459$.

McDowell, N. G., Michaletz, S. T., Bennett, K. E., Solander, K. C., Xu, C., Maxwell, R. M., \& Middleton, R. S. (2018). Predicting chronic climate-driven disturbances and their mitigation. Trends in Ecology and Evolution, 33(1), 15-27. https://doi.org/10.1016/j.tree.2017.10.002

Megonigal, J. P., Brewer, P. E., \& Knee, K. L. (2020). Radon as a natural tracer of gas transport through trees. New Phytologist, 225(4), 1470-1475. https://doi.org/10.1111/nph.16292 
Megonigal, J. P., \& Guenther, A. B. (2008). Methane emissions from upland forest soils and vegetation. Tree Physiology, 28(4), 491-498. https://doi.org/10.1093/treephys/28.4.491

Megonigal, J. P., Hines, M. E., \& Visscher, P. T. (2003). Anaerobic metabolism: Linkages to trace gases and aerobic processes. In H. D. Holland, \& G. Turekian (Eds.), Treatise on geochemistry (8-9, pp. 317-424). Oxford, UK: Pergamon. https://doi.org/10.1016/ B0-08-043751-6/08132-9

Meinzer, F. C., Campanello, P. I., Domec, J. C., Gatti, M. G., Goldstein, G., Villalobos-Vega, R., \& Woodruff, D. R. (2008). Constraints on physiological function associated with branch architecture and wood density in tropical forest trees. Tree Physiology, 28(11), 1609-1617.

Mugnai, S., \& Mancuso, S. (2010). Oxygen transport in the sapwood of trees. In S. Mancuso \& S. Shabala (Eds.), Waterlogging signalling and tolerance in plants. (pp. 61-75). Berlin, Heidelberg: Springer Berlin Heidelberg. https://doi.org/10.1007/978-3-642-10305-6_4

Neubauer, S. C., \& Megonigal, J. P. (2015). Moving beyond global warming potentials to quantify the climatic role of ecosystems. Ecosystems, 18(6), 1000-1013. https://doi.org/10.1007/s10021-015-9879-4

Ni, X., \& Groffman, P. M. (2018). Declines in methane uptake in forest soils. Proceedings of the National Academy of Sciences, 115(34), $8587-8590$.

Noe, S. M., Kimmel, V., Hüve, K., Copolovici, L., Portillo-Estrada, M., Püttsepp, Ü., et al. (2011). Ecosystem-scale biosphere-atmosphere interactions of a hemiboreal mixed forest stand at Järvselja, Estonia. Forest Ecology and Management, 262(2), 71-81.

Norwood, M. (2020). Coastal forest seawater exposure increases stem methane concentration manuscript data, HydroShare. Retrieved from https://doi.org/10.4211/hs.17e9a223ffe64e768e6cb8b2a77c198d

Ojima, D. S., Valentine, D. W., Mosier, A. R., Parton, W. J., \& Schimel, D. S. (1993). Effect of land use change on methane oxidation in temperate forest and grassland soils. Chemosphere, 26(1-4), 675-685.

Oksanen, J., Guillaume, F., Blanchet, F. M., Kindt, R., Legendre, P., McGlinn, D., et al. (2019). Vegan: Community ecology package. R package version 2.5-6

Osman, K. T. (2013). Wetland soils. In K. T. Osman (Ed.), Soils (pp. 215-227). New York, NY; London, UK: Springer, Dordrecht.

Overpeck, J. T., Otto-Bliesner, B. L., Miller, G. H., Muhs, D. R., Alley, R. B., \& Kiehl, J. T. (2006). Paleoclimatic evidence for future ice-sheet instability and rapid sea-level rise. Science, 311(5768), 1747-1750. https://doi.org/10.1126/science.1115159

Pangala, S. R., Enrich-Prast, A., Basso, L. S., Peixoto, R. B., Bastviken, D., Hornibrook, E. R. C., et al. (2017). Large emissions from floodplain trees close the Amazon methane budget. Nature, 552(7684), 230-234. https://doi.org/10.1038/nature24639

Pangala, S. R., Moore, S., Hornibrook, E. R. C., \& Gauci, V. (2013). Trees are major conduits for methane egress from tropical forested wetlands. New Phytologist, 197(2), 524-531. https://doi.org/10.1111/nph.12031

Pitz, S. L., Megonigal, J. P., Chang, C.-H., \& Szlavecz, K. (2018). Methane fluxes from tree stems and soils along a habitat gradient. Biogeochemistry, 137(3), 307-320. http://dx.doi.org/10.1007/s10533-017-0400-3

Poffenbarger, H. J., Needelman, B. A., \& Megonigal, J. P. (2011). Salinity influence on methane emissions from tidal marshes. Wetlands, 31(5), 831-842. https://doi.org/10.1007/s13157-011-0197-0

Raich, J. W., \& Schlesinger, W. H. (1992). The global carbon dioxide flux in soil respiration and its relationship to vegetation and climate. Tellus B: Chemical and Physical Meteorology, 44(2), 81-99.

Rennenberg, H. (1999). The significance of ectomycorrhizal fungi for sulfur nutrition of trees. Plant and Soil, 215(2), 115-122. https://doi. org/10.1023/A:1004459523021

Rinn, F., Schweingruber, F. H., \& Schär, E. (1996). Resistograph and x-ray density charts of wood. Comparative evaluation of drill-resistance profiles and x-ray density charts of different wood species. Holzforschung, 50(4), 303-311.

RStudio Team. (2017). RStudio: Integrated development environment for R. Boston, MA: RStudio, Inc. Retrieved from http://www.rstudio. $\mathrm{com} /$

Ryan, M. G., \& Waring, R. H. (1992). Maintenance respiration and stand development in a subalpine lodgepole pine forest. Ecology, 73(6), $2100-2108$

Saunois, M., Bousquet, P., Poulter, B., Peregon, A., Ciais, P., Canadell, J. G., et al. (2016). The global methane budget 2000-2012. Earth System Science Data, 8(2), 697-751. https://doi.org/10.5194/essd-8-697-2016

Schieder, N. W., \& Kirwan, M. L. (2019). Sea-level driven acceleration in coastal forest retreat. Geology, 47(12), 1151-1155. https://doi. org/10.1130/G46607.1

Schieder, N. W., Walters, D. C., \& Kirwan, M. L. (2018). Massive upland to wetland conversion compensated for historical marsh loss in Chesapeake Bay, USA. Estuaries and Coasts, 41(4), 940-951. https://doi.org/10.1007/s12237-017-0336-9

Seyfferth, A. L., Bothfeld, F., Vargas, R., Stuckey, J. W., Wang, J., Kearns, K., et al. (2020). Spatial and temporal heterogeneity of geochemical controls on carbon cycling in a tidal salt marsh. Geochimica et Cosmochimica Acta, 282, 1-18.

Shendryk, I., Broich, M., Tulbure, M. G., \& Alexandrov, S. V. (2016). Bottom-up delineation of individual trees from full-waveform airborne laser scans in a structurally complex eucalypt forest. Remote Sensing of Environment, 173, 69-83.

Spicer, R., \& Holbrook, N. M. (2007). Effects of carbon dioxide and oxygen on sapwood respiration in five temperate tree species. Journal of Experimental Botany, 58(6), 1313-1320.

Ståhl, E. G. (1988). Transfer effects and variations in basic density and tracheid length of Pinus sylvestris L. populations (No 180). Faculty of Forestry, Swedish University of Agricultural Sciences. Retrieved from http://urn.kb.se/resolve?urn=urn:nbn:se:slu:epsilon-9-16

Teskey, R. O., \& Mcguire, M. A. (2007). Measurement of stem respiration of sycamore (Platanus occidentalis L.) trees involves internal and external fluxes of $\mathrm{CO} 2$ and possible transport of $\mathrm{CO} 2$ from roots. Plant, Cell and Environment, 30(5), 570-579. https://doi. org/10.1111/j.1365-3040.2007.01649.x

Teskey, R. O., Saveyn, A., Steppe, K., \& McGuire, M. A. (2008). Origin, fate and significance of CO2 in tree stems. New Phytologist, 177(1), 17-32. https://doi.org/10.1111/j.1469-8137.2007.02286.x

Wang, Z. P., Han, S. J., Li, H. L., Deng, F. D., Zheng, Y. H., Liu, H. F., \& Han, X. G. (2017). Methane production explained largely by water content in the heartwood of living trees in upland forests. Journal of Geophysical Research: Biogeosciences, 122(10), 2479-2489. https:// doi.org/10.1002/2017JG003991

Wang, W., McDowell, N. G., Ward, N. D., Indivero, J., Gunn, C., \& Bailey, V. L. (2019). Constrained tree growth and gas exchange of seawater-exposed forests in the Pacific Northwest, USA. Journal of Ecology, 107(6), 2541-2552. https://doi.org/10.1111/1365-2745.13225

Wanninkhof, R. (2014). Relationship between wind speed and gas exchange over the ocean revisited. Limnology and Oceanography: Methods, 12, 351-362. https://doi.org/10.4319/lom.2014.12.351

Ward, N. D., Indivero, J., Gunn, C., Wang, W., Bailey, V., \& McDowell, N. G. (2019). Longitudinal gradients in tree stem greenhouse gas concentrations across six Pacific Northwest coastal forests. Journal of Geophysical Research: Biogeosciences, 124(6), 1401-1412. https:// doi.org/10.1029/2019JG005064 
Warner, D. L., Villarreal, S., McWilliams, K., Inamdar, S., \& Vargas, R. (2017). Carbon dioxide and methane fluxes from tree stems, coarse woody debris, and soils in an upland temperate forest. Ecosystems, 20(6), 1205-1216.

Wickham, H., Averick, M., Bryan, J., Chang, W., McGowan, L., François, R., et al. (2019). Welcome to the tidyverse. Journal of Open Source Software, 4(43), 1686

Williams, C. A., Gu, H., MacLean, R., Masek, J. G., \& Collatz, G. J. (2016). Disturbance and the carbon balance of US forests: A quantitative review of impacts from harvests, fires, insects, and droughts. Global and Planetary Change, 143, 66-80.

Williams, K., MacDonald, M., \& Sternberg, L. S. L. (2003). Interactions of storm, drought, and sea-level rise on coastal forest: A case study. Journal of Coastal Research, 19(4), 1116-1121.

Willig, M. R., Moorhead, D. L., Cox, S. B., \& Zak, J. C. (1996). Functional diversity of soil bacterial communities in the tabonuco forest: Interaction of anthropogenic and natural disturbance. Biotropica, 28(4), 471-483.

Winterstein, F., Tanalski, F., Jöckel, P., Dameris, M., \& Ponater, M. (2019). Implication of strongly increased atmospheric methane concentrations for chemistry-climate connections. Atmospheric Chemistry and Physics, 19(10), 7151-7163. https://doi.org/10.5194/ acp-19-7151-2019 